\title{
Making chemical \& biological protective gloves vapour permeable reduces thermoregulatory strain better than making armour, respirator or overboots permeable
}

\author{
Christie Garson, Michael J Tipton, James R House \\ From 15th International Conference on Environmental Ergonomics (ICEE XV) \\ Portsmouth, UK. 28 June - 3 July 2015
}

\section{Introduction}

Wearing chemical and biological (CB) protective equipment causes thermoregulatory strain by restricting evaporative cooling. We identified [1] that a moisture vapour impermeable (MVIP) body armour liner (BAL) imposed a greater thermal burden than MVIP CB gloves $(G)$, overboots $(O)$ or respirator $(R)$. The previous study progressively and cumulatively removed these MVIP items across 5 conditions when wearing a CB protective suit. This study is a repeat, except that items were removed in isolation and replaced for subsequent conditions to maintain a more uniform thermal load across comparisons. The aims of this study were to quantify the thermal burden imposed by each MVIP item whilst maintaining a high thermal load between conditions to identify the potential benefits if future equipment was made moisture vapour permeable (MVP). A second aim was to determine whether the previous experimental design [1] influenced the thermal burden imposed by each MVIP item. We hypothesised that removal of a MVIP item would reduce heat strain in this order $\mathrm{BAL}>\mathrm{G}>\mathrm{R}>\mathrm{O}$.

\section{Methods}

Following a favourable ethical opinion, 13 males volunteered for this five-condition, repeated measures study, stepping at a light intensity $\mathrm{VO}_{2} 13.6 \mathrm{~mL} \cdot \mathrm{kg}^{-1} \cdot \mathrm{min}^{-1}$ ), interspersed with 20 -minute rest periods in a hot and dry environment $\left(40.5{ }^{\circ} \mathrm{C}\right.$ and $20 \%$ relative humidity) for a maximum of 170 minutes; the last hour being

\footnotetext{
* Correspondence: jim.house@port.ac.uk

Extreme Environments Laboratory, Department of Sport and Exercise Science, University of Portsmouth, Portsmouth, UK
}

continuous work. Conditions varied in which combinations of MVIP items were worn with a CB suit. In Control (CON) all items were worn, in subsequent conditions, only one item was removed: $N_{R}$ (no $R$ ), $\mathrm{N}_{\text {BAL }}$ (no BAL), $\mathrm{N}_{G}$ (no $G$ ) and $\mathrm{N}_{\mathrm{OB}}$ (no O). When removed the mass of the item was substituted at the same body site thereby simulating that item 100\% MVP but without reducing the metabolic cost of wearing the item.

\section{Results}

Removing G reduced thermoregulatory strain most, as 7 participants completed the full $60 \mathrm{~min}$ of stepping in the final work period compared to $1(\mathrm{CON}), 2\left(\mathrm{~N}_{\mathrm{OB}}\right), 5$ $\left(\mathrm{N}_{\mathrm{R}}\right)$ and $5\left(\mathrm{~N}_{\mathrm{BAL}}\right)$. Removing $\mathrm{G}$ attenuated the rate of increase in rectal temperature $\left(\mathrm{T}_{\mathrm{re}}\right)$ during the final work period compared to CON by $0.37^{\circ} \mathrm{C} \cdot \mathrm{hr}^{-1}$ (p < 0.001 ) resulting in a $6 \%$ extension to stepping time during the final work period $(\mathrm{p}<0.05)$. Predicted tolerance time (TT) to a $\mathrm{T}_{\mathrm{re}}$ of $40^{\circ} \mathrm{C}$ (participants stopped when $\left.\mathrm{T}_{\mathrm{re}}=39^{\circ} \mathrm{C}\right)$ was extended by $13.3 \%(\mathrm{p}<0.01)$. In $\mathrm{N}_{\mathrm{G}}$, the rate of cooling was augmented in the final rest period with the final change in $\mathrm{T}_{\mathrm{re}}$ lowered by $0.14^{\circ} \mathrm{C}(\mathrm{p}<$ 0.01 ). The rise in mean body temperature was attenuated from 90 minutes with the greatest attenuation being $0.24^{\circ} \mathrm{C}(\mathrm{p}<0.0001)$ in $\mathrm{N}_{\mathrm{G}}$. During $\mathrm{N}_{\mathrm{G}}$ the physiological strain index (PSI) was reduced by $12.7 \%$ ( $<$ $0.001)$. Removing $G$ also reduced RPE during Rest 2 $(\mathrm{p}<0.05)$, final work $(\mathrm{p}<0.001)$ and final rest $(\mathrm{p}<$ $0.0001)$ and improved ratings of thermal comfort during final work $(\mathrm{p}<0.01)$ and rest $(\mathrm{p}<0.001)$. Removing BAL increased sweat evaporation by $10.2 \%$, yet did not extended TT. Removing R improved the PSI by $15.7 \%$ 
( $\mathrm{p}<0.05)$ but did not improve TT. Removing O did little to reduce thermoregulatory strain.

\section{Conclusion}

With the thermal load maintained across conditions, removal of any of the MVIP items reduced the thermal burden with removing $\mathrm{G}$ causing the greatest reduction to thermoregulatory strain. This is in contrast to [1] where BAL afforded the biggest benefit when removed. This method rather than [1] offers a better assessment of the contributing burden of protective equipment in human studies. We partly accept our hypothesis; thermal strain was reduced most by removing G, not BAL.

Published: 14 September 2015

\section{Reference}

1. Garson C, Dennis M, Tipton MJ, House JR: Individual and cumulative benefits of making body armour and chemical \& biological protective gloves, respirator and overboots from moisture vapour permeable materials. Extreme Physiology \& Medicine 2015, 4(Suppl 1):A96.

doi:10.1186/2046-7648-4-S1-A65

Cite this article as: Garson et al: Making chemical \& biological protective gloves vapour permeable reduces thermoregulatory strain better than making armour, respirator or overboots permeable. Extreme Physiology \& Medicine 2015 4(Suppl 1):A65.

\section{Submit your next manuscript to BioMed Central} and take full advantage of:

- Convenient online submission

- Thorough peer review

- No space constraints or color figure charges

- Immediate publication on acceptance

- Inclusion in PubMed, CAS, Scopus and Google Scholar

- Research which is freely available for redistribution

Submit your manuscript at www.biomedcentral.com/submit 